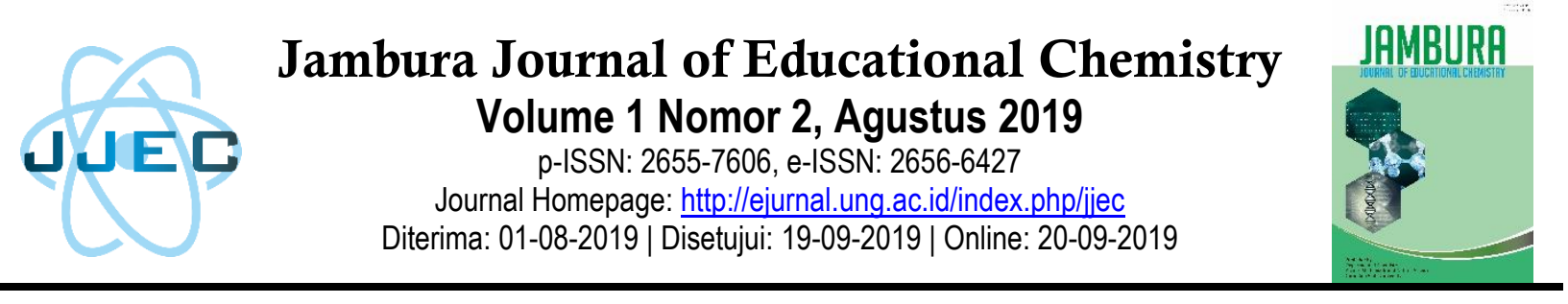

\title{
Keefektifan Program Pembelajaran Kimia Dasar : Evaluasi Model CIPP Pada Jurusan MIPA STKIP Gotong Royong Masohi
}

\author{
Maryone Saija1, Marlen Sahureka², Lazarus Kalvein Beay3 , dan Umar Namakule ${ }^{4}$ \\ 1,4Program Studi Pendidikan Biologi, STKIP Gotong Royong Masohi, Jl. Trans Seram Belakang \\ Negeri Haruru, Masohi, 97514 \\ 2Program Studi Pendidikan Matematika, STKIP Gotong Royong Masohi, Jl. Trans Seram \\ Belakang Negeri Haruru, Masohi, 97514 \\ ${ }^{3}$ SMA Negeri 1 Teluk Elpaputih, Dinas Pendidikan dan Kebudayaan Provinsi Maluku, Jl,Trans \\ Seram 97517 \\ e-mail: 1maryonesaija88@gmail.com
}

\begin{abstract}
Abstrak
Penelitian ini bertujuan untuk mengetahui penerapan model evaluasi CIPP dan perbedaan hasil belajar kognitif mahasiswa pada mata kuliah Kimia Dasar sebelum dan sesudah perbaikan program pembelajaran. Subjek penelitian terdiri dari 2 dosen pengampu mata kuliah dan 73 mahasiswa Jurusan Pendidikan MIPA-STKIP Gotong Royong Masohi. Pengumpulan data pada setiap proses evaluasi pembelajaran model CIPP menggunakan instrumen panduan wawancara; panduan observasi; lembar penilaian proses; dan studi dokumen. Data hasil penelitian dideskripsikan dalam bentuk naratif. Berdasarkan hasil penelitian dapat disimpulkan bahwa proses pembelajaran Kimia Dasar di STKIP Gotong Royong Masohi dinilai telah cukup efektif, dengan beberapa perbaikan sebagai bentuk umpan balik dari hasil penilaian produk. Efektifitas program pembelajaran setelah perbaikan dapat terlihat dari peningkatan jumlah nilai akhir (predikat A, B, dan C) mahasiswa. Berdasarkan nilai KKM $\geq 60$, maka dapat disimpulkan bahwa keberhasilan belajar untuk kelas Biologi sebanyak 40 mahasiswa atau 95,23\%, sedangkan untuk kelas Matematika sebanyak 29 mahasiswa atau sebesar 93,55\%.
\end{abstract}

Kata kunci: model CIPP; pembelajaran kimia dasar.

\section{PENDAHULUAN}

Kimia dasar merupakan salah satu mata kuliah umum, yang wajib diselesaikan oleh mahasiswa berdasarkan capaian kurikulum di STKIP Gotong Royong Masohi. Mata kuliah kimia dasar dibagi menjadi dua jenjang yakni kimia dasar I dan kimia dasar II. Selanjutnya, pembelajaran kimia dasar merupakan mata kuliah prasyarat untuk Biokimia. Oleh sebab itu, pembelajaran kimia harus mencapai ketuntasan dengan pencapaian yang telah ditentukan. Pencapaian ketuntasan pembelajaran kimia, secara berkala harus di evaluasi untuk meningkatkan kualitas hasil.
Faktor-faktor pembelajaran yang mempengaruhi kualitas hasil belajar, seperti minat dan motivasi mahasiswa, kelengkapan sarana, kurikulum, kesiapan dosen, bahan ajar, dll. Hal ini dapat dievaluasi untuk menilai ketercapaian tujuan pembelajaran. Selain itu, untuk dapat mencapai tujuan pembelajaran kimia yang maksimal sangat diperlukan evaluasi dan monitoring sebagai dasar perbaikan program. Evaluasi pembelajaran bukan hanya mengungkapkan pemahaman mahasiswa terhadap materi ajar, tetapi juga harus dapat mengungkapkan sejauh mana hal itu dapat diaplikasikan dalam kehidupan sehari-hari. 
Berbagai model evaluasi program pembelajaran telah ada untuk menjawab berbagai proses pengambilan keputusan dan penentuan keberlanjutan suatu program. Model evaluasi muncul karena adanya usaha secara kontinu yang diturunkan dari perkembangan pengukuran dan keingintahuan manusia untuk berusaha menerapkan prinsip evaluasi pada cakupan yang lebih abstrak termasuk pada bidang ilmu pendidikan (Bhakti, 2017).

Salah satu model evaluasi yang banyak dikenal dan diterapkan oleh para evaluator adalah konsep evaluasi model CIPP (Context, Input, Process and Product). Model CIPP pertama kali dikenalkan oleh Stufflebeam (2003) pada 1965, yang menyatakan bahwa tujuan utama model CIPP bukan hanya untuk membuktikan tetapi untuk memperbaiki. Keempat komponen model CIPP (Contexs, Input, Prosess, Product) merupakan komponen yang yang saling berinteraksi secara dinamis dan tidak berdiri sendiri (Muyana, 2017).

Sebagai mata kuliah dasar wajib (prasyarat) maka pembelajaran Kimia Dasar diharapkan dapat tepat sasaran sesuai dengan kebutuhan ilmu mahasiswa di Jurusan MIPA. Oleh sebab itu, proses penilaian program pembelajaran dalam evaluasi CIPP dilaksanakan dengan tujuan untuk mengetahui pemahaman dan penguasaan mahasiswa terhadap indikator pencapaian. Hasil evaluasinya diharapkan dapat dilaksanakan secara berkelanjutan mengikuti pencapaian hasil belajar. Informasi yang diperoleh dari evaluasi model CIPP, dapat menjadi dasar perbaikan pembelajaran kimia. Sehingga hasil penilaian produk sering dipakai sebagai umpan balik terhadap proses belajar.

Mengingat pentingnya proses evaluasi sebagai upaya untuk mendapatkan informasi secara menyeluruh dan utuh tentang hasil belajar mahasiswa disimpulkan bahwa permasalahan pada penulisan ini sebagai berikut.

1. Bagaimana penerapan model evaluasi CIPP pada pembelajaran Kimia Dasar di Jurusan Pendidikan MIPA STKIP Gotong Royong Masohi?

2. Bagaimana perbedaan hasil belajar kognitif Kimia Dasar mahasiswa Jurusan Pendidikan MIPA-STKIP Gotong Royong Masohi sebelum dan sesudah perbaikan program pembelajaran?

\section{METODE PENELITIAN Jenis Penelitian}

Penelitian evaluasi dan monitoring pembelajaran menggunakan model CIPP ini merupakan penelitian kualitatif yang pada proses deskripsi data dalam bentuk naratif. Namun, untuk tahapan evaluasi produk menggunakan data kuantitatif berupa nilai akhir sebagai bentuk perbandingan hasil belajar mahasiswa dalam dua semester.

\section{Waktu dan Tempat Penelitian}

Pelaksanaan penelitian ini bertempat pada kampus STKIP Gotong Royong Masohi, Jurusan Pendidikan MIPA. Proses penelitian berlangsung selama periode akademik 2017/2018 - 2018/2019.

\section{Subjek Penelitian}

Subjek penelitian ini yaitu 2 dosen pengampu mata kuliah Kimia Dasar; dan seluruh mahasiswa yang melakukan penawaran dan mengikuti setiap proses perkuliahan pada mata kuliah Kimia Dasar I dan II. Jumlah mahasiswa yang menjadi subjek penelitian adalah sebanyak 73 mahasiswa, masing-masing terdiri dari 42 mahasiswa pada kelas Biologi (gabungan dari 2 kelas Biologi) dan 31 mahasiswa pada kelas Matematika.

\section{Prosedur dan Teknik Pengumpulan Data}

Prosedur penelitian ini dilakukan secara berkelanjutan, dimulai dengan observasi awal; pengumpulan data; analisis data; penulisan laporan; sampai pada penarikan kesimpulan. Instrumen yang digunakan pada penelitian ini diproses melalui validasi oleh ahli. Penilaian yang dilakukan oleh ahli menggunakan indikator yang telah disusun dalam lembar validasi. Validitas instrumen diukur dengan menggunakan validasi isi dan validasi konstruk (Sukmadinata, 2012). Validasi konstruk yang dipakai adalah pendapat para ahli (judgment experts) (Sugiyono, 2013). Lawshe \& Martuza (dalam Ruslan, 2009) membahas metode statistika untuk menentukan validitas isi dan reliabilitas menyeluruh dan melalui penilaian pakar. Relevansi 
kedua pakar secara menyeluruh merupakan validitas isi Gregory, yaitu berupa koefisien validitas isi.

Pengumpulan data pada setiap proses evaluasi pembelajaran model CIPP menggunakan instrumen panduan wawancara; panduan observasi; lembar penilaian proses; dan studi dokumen. Proses evaluasi dan monitoring CIPP merujuk pada Stufflebeam (2007), sebagai berikut.

1. Penilaian konteks meliputi profil STKIP Gotong Royong, latar belakang program pembelajaran Kimia Dasar, faktor geografisdemografis, dan latar belakang sosial ekonomi dan pendidikan orang tua mahasiswa. Data hasil penilaian konteks akan digunakan sebagai dasar pertimbangan penggunaan program.

2. Penilaian input meliputi mahasiswa, kurikulum, bahan ajar, dan dosen serta sarana belajar. Data dikumpulkan selama tahap penilaian digunakan sebagai pengambil keputusan (Bhakti, 2017).

3. Penilaian proses adalah kegiatan penilaian selama pembelajaran, yakni aktivitas belajar; penggunaan media pembelajaran; penggunaan laboratorium; dan pemberian tugas.

4. Penilaian produk (output) merupakan proses penilaian pelaksanaan program. Penilaian dilakukan dengan tujuan mengetahui ketercapaian pelaksanaan pembelajaran Kimia Dasar berdasarkan kriteria yang ditetapkan. Penilaian produk berupa hasil belajar mahasiswa selama periode tahun ajaran.

Proses evaluasi dan monitoring ini terbagi dalam dua tahap yakni proses evaluasi dan perbaikan produk berdasarkan nilai akhir semester mahasiswa. Hal ini bertujuan untuk memperbaikan hasil belajar mahasiswa berdasarkan perbaikan input dan proses.

\section{HASIL DAN PEMBAHASAN}

Hasil evaluasi dan monitoring program pembelajaran Kimia Dasar pada Jurusan MIPA STKIP Gotong Royong Masohi dapat dilihat pada narasi proses sebagai berikut.

\section{Evaluasi Konteks (context evaluation)}

Evaluasi konteks dalam program pembelajaran Kimia Dasar dimulai dari profil tempat pembelajaran dilaksanakan. Tempat pembelajaran bernama STKIP Gotong Royong Masohi yang berlokasi di Jl. Trans Seram, Belakang Negeri Haruru, Masohi. Mahasiswa yang menjadi subjek pada penulisan ini adalah yang mengambil mata kuliah Kimia Dasar I dan Kimia Dasar II. Tim Pengajar berjumlah 2 orang dosen.

\begin{tabular}{lll}
\multicolumn{3}{c}{ Bentuk fisik bangunan STKIP Gotong } \\
Royong Masohi layak untuk
\end{tabular}
menyelenggarakan pendidikan. Ruangan yang terdapat untuk pembelajaran sebanyak 8 kelas; perpustakaan; Laboratorium IPA; 2 Lab Komputer (jarang difungsikan); Auditorium; Masjid; Lapangan Olahraga. Pada periode observasi dengan Mata Kuliah Kimia Dasar I, perpustakaan; ruang Lab IPA; dan Komputer tidak difungsikan untuk pembelajaran karena akses yang tidak jelas. Namun dimaksimalkan pemakaiannya pada periode mata kuliah Kimia Dasar II. Selain itu, dosen dapat mengakses pemakaian infocus yang sangat mendukung proses pembelajaran.

\section{Evaluasi Input (input evaluation)}

Sajian aspek input dalam proses evaluasi CIPP pada pembelajaran Kimia Dasar ini meliputi: (a) mahasiswa yang mengikuti pendidikan di Program Studi Pendidikan Biologi dan Pendidikan Matematika-STKIP Gotong Royong Masohi; (b) kurikulum (Silabus dan RPS); (c) bahan ajar; (d) Dosen; dan (e) sarana dan prasarana belajar. Revisi kurikulum dan bahan ajar yang dilakukan oleh dosen dengan tujuan untuk mencapai kebutuhan materi ajar pada program studi Biologi dan Matematika. Materi ajar yang tepat sasaran sesuai kebutuhan Jurusan MIPA adalah konsep kimia modern; persamaan kimia; wujud zat; larutan; termodinamika kimia; kesetimbangan kimia; asambasa; elektrokimia; kinetika kimia; dan molekulmolekul organik; pengikatan logam transisi dan kompleks koordinasi; dan polimer

\section{Evaluasi Proses (process evaluation)}

Proses pelaksanaan pembelajaran terbagi menjadi dua bagian penting, yaitu persyaratan pelaksanaan pembelajaran dan pelaksanaan pembelajaran. Hasil evaluasi proses sebagai berikut:

a. Persyaratan pelaksanaan pembelajaran

Persyaratan pertama, untuk mahasiswa yang menawarkan mata kuliah Kimia Dasar II 
sudah harus lulus pada Kimia Dasar I. Selain persyaratan ini, hanya ada persyaratan administratif menyangkut status akademik mahasiswa. Selain itu, untuk mengetahui prior knowledge mahasiswa maka dosen melaksanakan tes awal sebelum proses pembelajaran. Hal ini dilakukan karena mahasiswa berasal dari latar belakang sekolah yang berbeda dan berada pada lokasi daerah 3T, sehingga dosen harus menyusun bahan ajar yang disesuaikan dengan kebutuhan awal mahasiswa.

Persyaratan kedua, beban kinerja untuk dosen. Beban kerja dosen mencakup kegiatan pokok yaitu merencanakan pembelajaran, melaksanakan pembelajaran, menilai hasil pembelajaran, membimbing dan melatih mahasiswa, serta melaksanakan tugas tambahan. Perencanaan pembelajaran yang dilakukan oleh dosen meliputi pembuatan Silabus, Rencana Pelaksanaan Semester (RPS), dan distribusi alokasi waktu.

Buku ajar dan Lembar Kerja Mahasiswa (LKM) yang harus dimiliki oleh mahasiswa untuk mata kuliah Kimia Dasar sudah terpenuhi dengan perhitungan satu buku per satu mahasiswa. Penggunaan buku ajar dan KLM ini diwajibkan bagi mahasiswa, sebagai sumber tambahan referensi bagi pengembangan wawasan ilmu. Pengelolaan kelas dilakukan sebelum ketika pembelajaran berlangsung sesuai dengan metode pembelajaran yang dipakai serta disesuaikan dengan materi yang akan dibahas. Berdasarkan hasil pembahasan diatas dapat disimpulkan bahwa persyaratan pembelajaran dapat dikategorikan cukup efektif dengan adanya kelengkapan prasyarat bagi mahasiswa, maka beban kerja dosen yang tidak terlalu berat. Selain itu, jumlah buku ajar dan LKM yang mencukupi serta pengelolaan kelas yang lengkap dan terorganisasi dengan baik. Buku ajar dan LKM direvisi sesuai dengan kebutuhan materi ajar bagi Jurusan MIPA.

\section{b. Pelaksanaan pembelajaran}

Observasi aspek pelaksanaan pembelajaran didasarkan pada indikator pelaksanaan pembelajaran yang dipakai oleh Bhakti (2017) yakni (1) mengelola ruang dan fasilitas pembelajaran; (2) melaksanakan kegiatan pembelajaran; (3) mengelola interaksi kelas; (4) bersikap terbuka dan luwes serta membentuk dan mengembangkan sikap postif ketika belajar; (5) Demonstrasi atau pengelolaan praktikum mini dikelas; (6) melaksanakan evaluasi proses dan hasil belajar; dan (7) kesan umum kinerja dosen. Aspek pelaksanaan pembelajaran ini memenuhi kriteria cukup efektif. Penilaian proses pembelajaran dilakukan dan dibutikan pada forum diskusi dosen yang dilaksanakan setiap minggu, secara rutin terkoordinasi oleh beberapa dosen Jurusan MIPA. Hasilnya merupakan perbaikan proses pembelajaran dengan metode yang lebih baik pada semester berikutnya. Proses perbaikan ini dapat terlihat pada perbandingan perolehan nilai akhir semester mahasiswa sebagai hasil dari evaluasi produk.

\section{Evaluasi Produk (product evaluation)}

Proses evaluasi produk dalam program pembelajaran Kimia Dasar ini meliputi nilai akhir mahasiswa pada mata kuliah Kimia Dasar I dan Kimia Dasar II. Perbandingan hasil belajar mahasiswa selama periode evaluasi dan monitoring, yaitu sebelum dan sesudah perbaikan program pembelajaran sebagai berikut.

Tabel 1. Perbandingan Nilai (Predikat) Akhir Mahasiswa Kelas Biologi

\begin{tabular}{ccc}
\hline \multirow{2}{*}{ Predikat } & \multicolumn{2}{c}{ Frekuensi } \\
& Sebelum & Sesudah \\
\hline A & 3 & 9 \\
B & 15 & 24 \\
C & 9 & 7 \\
D & 5 & 1 \\
E & 10 & 1 \\
\hline
\end{tabular}

Tabel 2. Perbandingan Nilai (Predikat) Akhir Mahasiswa Kelas Matematika

\begin{tabular}{ccc}
\hline \multirow{2}{*}{ Predikat } & \multicolumn{2}{c}{ Frekuensi } \\
& Sebelum & Sesudah \\
\hline A & 3 & 9 \\
B & 13 & 18 \\
C & 9 & 2 \\
D & 1 & 0 \\
E & 5 & 2 \\
\hline
\end{tabular}

Data pada tabel 1 dan 2 menunjukan bahwa telah terjadi peningkatan nilai hasil belajar kognitif Kimia Dasar. Hal ini dibuktikan dengan meningkatnya jumlah (frekuensi) mahasiswa yang mendapat predikat $\mathrm{A}, \mathrm{B}$, dan $\mathrm{C}$ pada semester berikutnya. Berdasarkan nilai $\mathrm{KKM} \geq 60$, maka dapat disimpulkan bahwa keberhasilan belajar untuk kelas Biologi sebanyak 40 mahasiswa atau 95,23\%, sedangkan untuk kelas Matematika sebanyak 29 mahasiswa atau sebesar 93,55\%. 


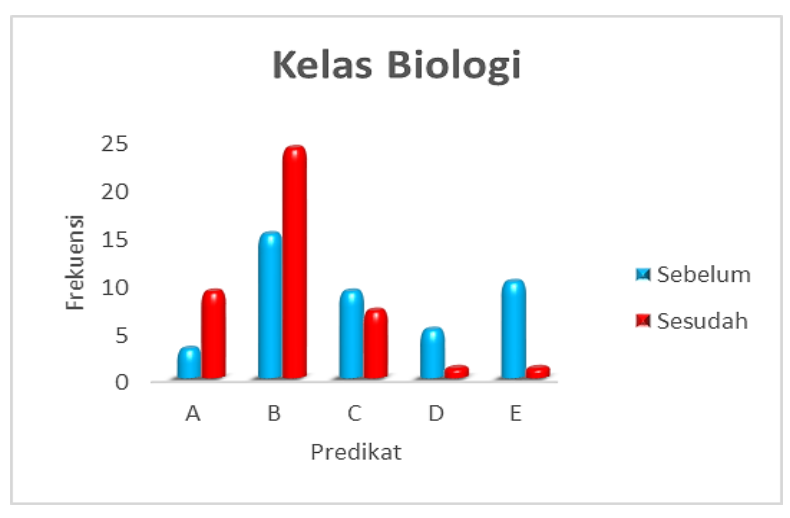

Gambar 1. Grafik Perbandingan Nilai Akhir (Predikat) Mahasiswa Kelas Biologi

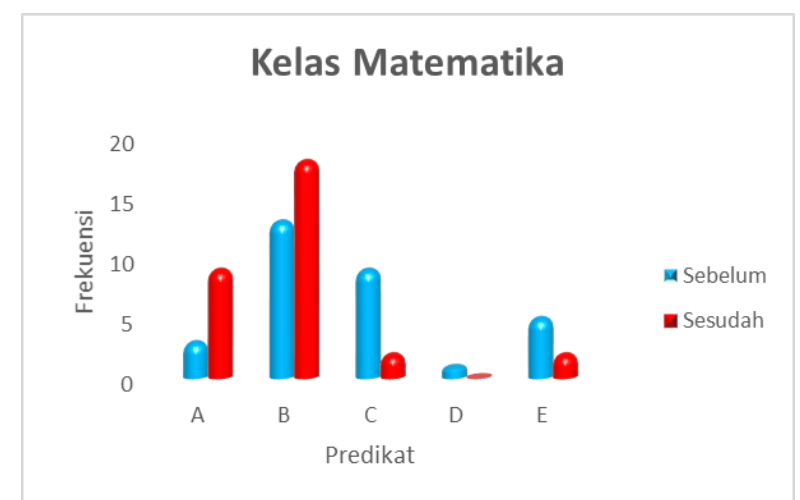

Gambar 2. Grafik Perbandingan Nilai Akhir (Predikat) Mahasiswa Kelas Matematika

Perbaikan program pembelajaran berdasarkan hasil evaluasi dan monitoring input dan proses. Proses pembelajaran yang menggunakan metode hands-on (mahasiswa terlibat langsung), misalnya dengan Model Pembelajaran RQA, demonstrasi, bahkan narasi ekpresif ilmiah akan menghasil nilai hasil evaluasi lebih baik bila dibadingkan dengan menggunakan model pembelajaran langsung (ceramah). Hal ini terjadi karena pada proses pembelajaran inovatif, mahasiswa lebih bisa mengingat dengan baik, mengeksplorasi kemampuan berpikir kreatif, sehingga mampu mengimplementasikan makna pembelajaran ke kehidupan sehari-hari. Hasil ini juga terlihat pada LKM serta pengerjaan tugastugas yang diberikan.

\section{SIMPULAN}

Proses pembelajaran Kimia Dasar di STKIP Gotong Royong Masohi dinilai telah cukup efektif. Hal ini dapat terlihat dari berbagai perbaikan aspek persyaratan pelaksanaan pembelajaran berupa kesiapan belajar, beban kerja dosen, jumlah buku ajar bahkan LKM serta pengelolaan kelas yang lengkap dan terorganisasi dengan baik. Selain itu, pelaksanaan kegiatan pembelajaran di kelas dinyatakan cukup efektif dengan dilakukannya beberapa perbaikan pada berbagai kekurangan yang seperti; (1) pengelolaan waktu pembelajaran yang kurang maksimal untuk mencapai tujuan pembelajaran; (2) mengoptimalkan penggunaan laboratorium maupun berbagai sarana lainnya dalam menunjang proses pembelajaran. Selain itu, efektifitas program pembelajaran Kimia Dasar juga terlihat dari meningkatnya frekuensi perolehan nilai akhir pada mahasiswa yang memperoleh predikat A, B, dan C. Meskipun terdapat kesulitan pada awal proses penilaian produk, namun secara bertahap proses perbaikan program dapat membuat mahasiswa menyadari akan pentingnya manfaat pembelajaran Kimia Dasar.

\section{DAFTAR PUSTAKA}

Bhakti, Y. B. (2017). Evaluasi Program Model pada Proses Pembelajaran IPA. Jurnal Inovasi Pendidikan Fisika dan Riset Ilmiah, 1(2), 7582.

Muyana, S. (2017). Context Input Process Product (CIPP) : Model Evaluasi Layanan Informasi. In Seminar Bimbingan dan Konseling, 1(1), 342-347.

Ruslan. (2009). Validitas Isi; Buletin Pa'biritta No.10 Tahun IV September 2009.

Stufflebeam, D. L. (2003). The CIPP Model For Evaluation. Retrieved February 26 2018, from https://www.scribd.com/document/58435354/ The-Cipp-Model-for-Evaluation-by-Daniel-1Stufflebeamj.

Stufflebeam, D. L. (2007). CIPP Evaluation Model Checklist (2nd Ed.). Retrieved February 26 2018, from http://www.wmich.edu/evalctr/archive_chec klists/cippchecklist. 
Sugiyono. (2013). Statistika Untuk Penelitian. Sukmadinata, N. S. (2012). Metode Penelitian Bandung: Alfabeta. 